\title{
Antioxidant Potential of Black, Greenand Oolong Tea Methanol Extracts
}

\author{
Wahyu Widowati ${ }^{1 *}$, Tati Herlina ${ }^{2}$, Hana Ratnawati ${ }^{1}$, Gabriella Constantia ${ }^{1}$, I Dewa Gde Sathya Deva ${ }^{3}$ and \\ Maesaroh Maesaroh ${ }^{3}$ \\ ${ }^{1}$ Medical Research Center, Faculty of Medicine, Maranatha Christian University Bandung, \\ Jl. Prof. Drg. Suria Sumantri MPH No 65, Bandung 40164, West Java, Indonesia \\ ${ }^{2}$ Chemist Program, Faculty of Mathematics and Natural Sciences, University of Padjadjaran, Bandung. West Java, Indonesia \\ ${ }^{3}$ Aretha Medika Utama Biomolecular and Biomedical Research Center, Bandung \\ Jl. Babakan Jeruk 2 no 9, Bandung 40163, West Java, Indonesia
}

Author correspondency*:
wahyu_w60@yahoo.com

\begin{abstract}
Degenerative diseases and chronic diseases are often caused by oxidative stress. Oxidative stress caused by free radicals. Antixodant as inhibitor are needed to prevent it which is one of antioxidant sources is tea. Tea processing generally produce various kinds of teas such as black, green and oolong tea. Tea processing affect the content of phenolic compounds. The aim of the research is to evaluate phytochemical content, total phenolic content of black tea, green tea and oolong tea extracts using catechin, quercetin, kaempferol, myricetin as standard, and to evaluate the antioxidative potency of black tea, green tea and oolong tea extracts compared to catechin, quercetin, kaempferol, myricetin. Phytochemical assay using modified Farnsworth method, the antioxidant activity were measured by by its 1,1-diphenyl-2-picrylhydrazyl (DPPH) scavenging activity. Green tea extract contained highest phenolic and flavonoid. The highest antioxidant activity was green tea extract with $I C_{50}=0,487 \mu \mathrm{g} / \mathrm{mL}$. Green tea extract content phenol and flavonoid are higher compared to the other extracts, green tea extract has the highest antioxidant activity.
\end{abstract}

Keywords: antioxidant, black tea extract, green tea extract, oolong tea extract, total phenolic content

\section{Introduction}

Various degenerative and chronic diseases are often caused by oxidative stress. Oxidative stress is caused by free radicals. It highly reactive and unstable because of its unpaired electron in the outer atomic orbital. Free radical can react with the cells molecules by binding to it. It can oxidize the nucleic acid, proteins, fats and even the cells DNA and initiate the degenerative disease (Halliwell \& Gutteridge, 2007). Free radicals are derived either from normal essential metabolic process in the human body or from external exposure (Bagchi \& Puri, 1998). The antioxidants as oxidation inhibitor are needed to overcome the negative effect of the free radicals. Antioxidant inhibits the oxidation by reacting to reactive free radicals to form reactive substances that relatively stable. Endogenous antioxidant already present in the human body. However the exogenous antioxidant still needed if the free radicals present in copious amounts (Johnson, 2002). A balance between free radicals and antioxidant is necessary for proper physiological function. Antioxidant may exert their effect on biological systems by different mechanism, including electron donation, metal ion chelation, co-antioxidants, or by gene expression regulation (Krinsky, 2000; Lobo et al., 2010).

There are two kinds of antioxidant based on its source, natural antioxidant and synhetic antioxidant. Synthetic antioxidants are carcinogenic when it consumed for long term. The needs of natural antioxidant that have fewer side effect and less toxic continues to rise.Natural antioxidants can protect the body against the damage caused by reactive oxygene species (ROS), inhibit the degenerative disease and inhibit the lipid peroxidase activity (Wiseman et al., 1997). Tea-one of the most popular beverage- components possess antioxidant activity.Most commercially prepared tea is obtained form the leaf of the plant Camelia sinensis (Satoh et al., 2005). Among tea, $69 \%$ of consumption is black tea, $28 \%$ of consumption is green tea and $3 \%$ others is oolong tea (Cabrera et al., 2008). Teas of C.sinensis undergo different manufacturing processes. Green tea is produced by steaming (Japan) or panning (China) to prevent cathechin oxidation by polyhenol oxidase. Oolong tea is semi-fermented while black tea is fully fermented (Eric et al., 2011). Many studies have shown that green, black and oolong tea has antioxidant properties (Xie et al., 1993; Wiseman, 1997; McKay \& Blumberg, 2002; Zhu et al., 2002; Higdon \& Frei, 2003; Satoh et al., 2005). Tea processing will affect the phenol content and ultimately will affect the antioxidant activity of it (Higdon \& Frei, 2003). Therefore, it become important to investigate the antioxidant activity of the extract of black tea, green tea, and oolong tea and test the phenol content based on the cathechin, quercetin, kaempferol and myricetin standard.

\section{Methodology}

Plant material preparation, extraction and phyrochemical content assay

Dried leaves green tea and black tea were obtained from Cisaruni Plantation, PTPN VIII, West Java, Indonesia 
and dried oolong tea was obtained from Tea Plantation, East Java. Extraction was performed based on maceration method using methanol $96 \%$ as the solvent (Widowati et al., 2011a; Widowati et al., 2013a; Widowati et al., 2014a; Widowati et al., 2014b). The extraction yielded $20.139 \%$ of black tea, $22.11 \%$ of green tea, and $17.39 \%$ of oolong tea. The green tea, black tea, and oolong tea extract were tested by phytochemical assay using modified Fransworth method including terpenoid, phenol, steroid, triterpenoid, flavonoid, tannin, alkaloid, and saponin assay (Fransworth et al., 1966; Widowati et al., 2010; Bera et al., 2014).

\section{Total Phenol Assay}

Briefly $25 \mu \mathrm{L}$ standard solution in 10 concentration level $(500 ; 250 ; 125 ; 62,5 ; 31,25 ; 15,625 ; 7,81 ; 3,95 ; 1,98$; and $0,98 \mu \mathrm{g} / \mathrm{mL}$ ) of catechin, quercetin, kaempferol, and myricetin and sample (extract from green tea, black tea, and oolong tea) in concentration of $500 \mu \mathrm{g} / \mathrm{mL}$ were prepared for total phenol assay. Each standard and sampled was mixed with $125 \mu \mathrm{L}$ follin $10 \%$ and $100 \mu \mathrm{L}$ of $\mathrm{Na}_{2} \mathrm{CO}_{3} \quad 7,5 \%$ in microplate. The reaction then incubated at $45^{\circ}-50^{\circ} \mathrm{C}$ for 10 minutes. The absorbance was measured in $760 \mathrm{~nm}$ of wavelength using microplate reader. The linear regression equation $(\mathrm{y}=a+b)$ was created based on the standard (cathechin, quercetin, kaempferol, myricetin) absorbance value. The analysis of phenol content of sample was performed based on the each of standard linear regression equation (Ivanova et al., 2005; Widowati et al., 2011a; Widowati et al., 2015).

\section{DPPH scavenging activity assay}

DPPH (2,2-diphenyl-1-picrylhydrayl) free radical scavenging activity were analyzed based on the linear regression equation continued by median Inhibitory Concentration $\left(\mathrm{IC}_{50}\right)$ value determination. Ten concentration levels $(500 ; 250 ; 125 ; 62,5 ; 31,25 ; 15,625$; 7,$8 ; 3,9 ; 1,9 ;$ and $0,9 \mu \mathrm{g} / \mathrm{mL}$ ) of black tea, green tea,and oolong tea extract as working solution was prepared for this assays. Briefly, $50 \mu \mathrm{L}$ samples (working solution) were added to a microplate followed by $200 \mu \mathrm{L}$ DPPH (Sigma-Aldrich) solution $(0,077 \mathrm{mmol} / \mathrm{L}$ in methanol). The reaction was shaken vigorously and kept in the dark for 30 minutes at room temperatures. DPPH scavenging activity was determined by microplate reader at $517 \mathrm{~nm}$. Metanhol absolute was used as blanko. The $\mathrm{IC}_{50}$ value then determined. The radical scavenging activity of each sample was measured according to equation 1 (Han et al., 2004; Widowati et al., 2013b; Widowati et al., 2013c; Widowati et al., 2015).

$$
S \quad \%=\left(A_{C}-A_{S}\right) /\left(A_{C} \times 100\right)
$$

Description

$\mathrm{A}_{\mathrm{s}}=$ sample absorbance

$A_{c}=$ negative control absorbance (without sample)

\section{Results}

\section{Phytochemical content of tea extracts}

Table 1 shows the different phytochemical content, including terpenoid, phenol, steroid, triterpenoid, flavonoid, tannin, alkaloid, and saponin of green tea, black tea, and oolong tea methanol extract. All of phytochemical tested was found in the green tea extract. High level of phenol also found in green tea and oolong tea extract. Green tea also containts the highest level of alkaloid compared to the other tea extract. Otherwise, steroid and alkaloid did not observed in the black tea extract. Triterpenoid and tannin also not found in the oolong tea extract. Less content of saponin also found in all of the extract.

Table 1. Phytochemical content assay of black tea, green tea, and oolong tea methanol extract

\begin{tabular}{lcccccccc}
\hline \multirow{2}{*}{ Sample } & & \multicolumn{9}{c}{ Phytochemical assay } & & \\
& Terpenoid & Phenol & Steroid & Triterpenoid & Flavonoid & Tannin & Alkaloid & Saponin \\
\hline Black tea & ++ & ++ & - & + & ++ & + & - & + \\
Green tea & + & ++++ & + & + & +++ & + & +++ & + \\
Oolong tea & + & ++++ & ++ & - & +++ & - & + & + \\
\hline
\end{tabular}

Description:

++++ : very high content, $+++:$ high content, $++:$ moderate content, $\quad+:$ low content, $-:$ undetected

\section{Phenolic compound of tea extracts}

Statistical assay based on linear regression equation was performed to analyze the total phenol of black tea, green tea, and oolong tea based on the standard solution (cathechin, quercetin, kaempferol and myricetin). The highest level of total phenol was showed by green tea extract (Table 2). The degree of oxidation affected by the polyphenols profile of the tea. (Balentine et al., 1997). 
Table 2. The average of total phenol level concentration of black tea, green tea, and oolong tea $(\mu \mathrm{g} / \mathrm{mg})$.

\begin{tabular}{lcccc}
\hline Sample & $\begin{array}{c}\text { Catechin Equivalent } \\
(\text { CE) }\end{array}$ & $\begin{array}{c}\text { Quercetin Equivalent } \\
(\mathbf{Q E})\end{array}$ & $\begin{array}{c}\text { Kaempferol Equivalent } \\
\text { (KE) }\end{array}$ & $\begin{array}{c}\text { Myricetin Equivalent } \\
\text { (ME) }\end{array}$ \\
\hline Black tea extract & 14,33 & 4,50 & 4,33 & 4,17 \\
Green tea extract & 23,33 & 9,71 & 4,33 & 6,17 \\
Oolong tea extract & 16,08 & 5,09 & 3,33 & 4,67 \\
\hline
\end{tabular}

\section{DPPH Scavenging Activity}

The most active extract in DPPH scavenging activity showed by green tea extract indicated by the lowest $\mathrm{IC}_{50}$ value compared to the other extract and standard (Table 3). DPPH is a stable free radical because of the unpaired electron. The unpaired electron of the radical becomes paired in the presence of hydrogen donor, decreasing the absorption in $517 \mathrm{~nm}$ of wavelength. The DPPH scavenging activity has been widely used to test the compound ability as a free radical scavenger and antioxidant activity in food or plat extract (Satoh et al., 2005). Previous study already obtained that the black tea has the antioxidant activity through DPPH free radical scavenging activity with $\mathrm{IC}_{50}=5,405 \mu \mathrm{g} / \mathrm{mL}$ (Widowati et al., 2011a), catechin (C) diluted in methanol with $\mathrm{IC}_{50}$ $=8.11 \mu \mathrm{M}$ (Evacuasiany et al., 2014) and catechin diluted in DMSO with $\mathrm{IC}_{50}=7.02 \mu \mathrm{g} / \mathrm{ml}$ (Budiman et al., 2014).

Table 3. Inhibitory Concentration $\left(\mathrm{IC}_{50}\right.$ ) Value of Antioxidant DPPH Scavenging Activities of Tea extract and Standard.

\begin{tabular}{|c|c|c|c|c|c|}
\hline Samples & Replication & Linear equation & $\mathbf{R}^{2}$ & $\underset{(\boldsymbol{\mu g} / \mathbf{m l})}{\mathbf{I} \mathbf{C}_{50}}$ & $\begin{array}{c}\text { Average } \\
\text { IC } 50\end{array}$ \\
\hline \multirow{3}{*}{ Green tea extract } & 1 & $Y=4,299 x+48,70$ & 0,767 & 0,30 & \multirow{3}{*}{$0,487 \pm 0,258$} \\
\hline & 2 & $Y=4,539 x+46,45$ & 0,735 & 0,78 & \\
\hline & 3 & $Y=4,342 x+48,37$ & 0,751 & 0,38 & \\
\hline \multirow{5}{*}{ Oolong te extract } & 1 & $Y=7,363 x+12,93$ & 0,911 & 5,03 & \multirow{5}{*}{$5,005 \pm 0,060$} \\
\hline & 2 & $Y=7,225 x+13,55$ & 0,918 & 5,04 & \\
\hline & 3 & $\mathrm{Y}=7,286 \mathrm{x}+14,03$ & 0,911 & 4,94 & \\
\hline & 2 & $Y=6,592 x+3,575$ & 0,989 & 7,04 & \\
\hline & 3 & $Y=6,666 x+3,671$ & 0,987 & 6,95 & \\
\hline \multirow{3}{*}{ Quercetin } & 1 & $Y=6,153 x+23,65$ & 0,901 & 4,28 & \multirow{3}{*}{$4,279 \pm 0,065$} \\
\hline & 2 & $\mathrm{Y}=6,095 \mathrm{x}+24,32$ & 0,893 & 4,21 & \\
\hline & 3 & $\mathrm{Y}=6,128 \mathrm{x}+23,39$ & 0,878 & 4,34 & \\
\hline \multirow{3}{*}{ Kaempferol } & 1 & $Y=8,731 x-11,662$ & 0,823 & 7.06 & \multirow{3}{*}{$7.154 \pm 0.134$} \\
\hline & 2 & $\mathrm{Y}=8,063 \mathrm{x}-8,924$ & 0,887 & 7.31 & \\
\hline & 3 & $Y=9,039 x-14,107$ & 0,827 & 7.09 & \\
\hline \multirow{3}{*}{ Myricetin } & 1 & $Y=12,803 x-6,749$ & 0,829 & 4,43 & \multirow{3}{*}{$4,496 \pm 0,058$} \\
\hline & 2 & $Y=11,588 x-4,270$ & 0,809 & 4,69 & \\
\hline & 3 & $Y=10,89 x+2,464$ & 0,719 & 4,37 & \\
\hline
\end{tabular}

\section{Discussion}

Tea is one of the most widely consumed beverages in the world which is grouped into three main groups, including green, black, and oolong tea, according to the fermentation process, Fermentation of tea can affect the phytochemical content of different tea extract confirmed by the result that highest phenol and flavonoid content was observed in green tea (non fermented tea) and oolong tea (semi fermented tea) compared to black tea (fully fermented tea). In the fermentation process, the catechin is oxidized resulting thearubigin, theaflavin including theaflavin (TF1), theaflavin-3-gallate (TF2A), theaflavin3'-gallate(TF2B), and theaflavin-3,3'-digallate (TF3B) which is the key component of the black tea flavour
(Leung et al., 2001;. Yang \& Landau, 2002; USDA, 2003). Phytochemical assay of green tea extract Catechins are a group of natural polyphenols found in green tea. Previous study of green tea exract using ehanol $70 \%$ resulted phenols $(+++)$, triterpenoids $(++)$, steroid () , terpenoids $(+++)$, saponins $(+)$, alkaloids $(++)$, flavonoids (++), tannins (+++) (Fanny et al., 2015). Different solvent concentration resulted different compounds, yield and bioacivities (Tiwari et al., 2011) The different solvent would result the different compound and bioactivity (Pujimulyani et al., 2004; Widowati et al., 2011b)., validated by previous study that water extract of Forsythia koreana flowers exhibited a higher phenolic content than ethanol extract (Yang and Kang, 2011). Otherwise, theaflavins are another group of polyphenol 
pigment found in both black and oolong teas.Oolong tea that partially oxidized and retains a considerable amount of the original catechin (Nor \& Mohd, 2003). Many studies have demonstrated that both catechin and theaflavin have strong free-radical-scavenging activity both in vivo and in vitro (Lai et al., 2001).

The chemical composition of tea includes proteins, polysaccharides, polyphenols (cathecins or flavan-3-ols, theaflavins, thearubigins, and proanthocyanidins), chlorophyll, minerals, and trace elements volatile compounds, amino and organic acids, lignins and alkaloid (Chen et al., 2009). Tea is wellknown for it health benefits because of its poliphenol bioactive content, especially chatechin which have antioxidants activity that play a role in reducing the free radical effect (Vecchia et al., 1992; Bravo et al., 1998; Nagao et al., 2005). Catechin belong to flavonoid that posses the high antioxidant activity in biological system. (Gramza et al., 2005; Evacuasiany et al., 2014)

According to the Table 2. the most active extract in DPPH scavenging activity was the green tea extract showed by the lower of $\mathrm{IC}_{50}$ values compared to the catechin, quercetin, kaempferol, and myricetin. The green tea extracts have the higher antioxidant activity through DPPH scavenging activity and $\mathrm{IC}_{50}$ value compared to the black tea extracts (Widowati et al., 2011a). That result is in accordance to the phytochemical assay (Table 1) and total phenol assay (Table 2) showed that the green tea extract containts the higher total phenol content compared to black tea and oolong tea extracts and the higher flavonoid compared to the black tea extracts. High correlations were observed between antioxidants activities and polyphenol phytochemicals content. The antioxidants activities most probably might be contributed by polyphenols contents in the plant extracts (Bakar et al., 2009; Ling et al., 2010; Nor \& Mohd, 2013).

The result of this study also confirmed that the green tea extract posses the higher antioxidant activity compared to the catechin, quercetin, kaempferol and myrietin. Table 2 also confirmed that teas extract contain catechin and various compound including quercetin, kaempferol and myricetin (Cabrera et al., 2006). Some research also investigated that black tea, oolong tea and green tea posses the antioxidant activity (Xie et al., 1993; Zhu et al., 2002). This study also in line with the research that polyphenol compound have antioxidant activity (Higdon \& Frei, 2003; Widowati et al., 2011a). Green tea is the good source of polyphenol especially for flavanol and flavonol compounds which is found in $30 \%$ of tea leaf dry mass (Wolfram et al., 2008). The antioxidant activity of green tea extracts was higher than oolong tea and black tea extracts (Gramza et al., 2005). Satoh et al (2005) also found that the green tea has the highest percent DPPH scavenging activity followed by roasted tea, oolong tea, and black tea respectivelly. That antioxidant activities have a strong correlation with the total phenolic content. The oxidation of flavanol in green tea may greatly contribute to the high antioxidant activities compared to the other kinds of tea (Von et al., 2000; Satoh et al., 2005).

\section{Conclusion}

The green tea metanhol extract have the higher total phenol content compared to the other extracts (black tea and oolong tea). Green tea extract aslo show the highest antioxidant DPPH scavenging activity. Hence, the need to exploit the potential of green tea in pharmaceutical industries arises.

\section{Acknowledgment}

We gratefully acknowledge the financial support of Directorate General of Higher Education, National Ministry of Republic Indonesia for research grant of Hibah Unggulan Strategis Nasional (2009-2011).

\section{References}

Bakar MFA, Mohamed M, Rahmat A, Fry J (2009) Phytochemicals and antioxidant activity of different parts of bambangan (Mangifera pajang) and tarap (Artocarpus odoratissimus). Food Chem 113:479-483.

Bagchi K, Puri S (1998) Free radicals and antioxidants in health and disease. EMHC 4: 350-360.

Balentine D, Wiseman S, Bouwers L (1997) The chemistry of tea flavonoids. Crit Rev Food Sci Nutr 37: 693-704.

Bera TK, Chatterjee K, Ghosh D (2014) In-vitro antioxidant properties of the hydro-methanol extract of the seeds of Swietenia mahagoni (L.) Jacq. Biomarkers Genomic Med 20: $1-7$

Bravo L (1998) Polyphenols:chemistry, dietary sources, metabolism, and nutritional significance. Nutr Rev 56:317333.

Budiman I, Tjokropranoto R, Widowati W, Rahardja F, Maesaroh M, Fauziah N (2014) Antioxidant and anti-malarial properties of catechins. British J Med Med Research 5(7): XX-XX

Cabrera C, Artacho R, Gimenez R (2006) Beneficial effects of green tea-a review. J Am Coll Nutr 25(2): 79-99.

Chen H, Zhishuang Q, Lingling F, Peng D, Xin Z (2009) Physicochemical properties and antioxidant capaity of 3 polysaccharides from green tea, oolong tea, and black tea. $\mathrm{J}$ Food Sci 74(6): 469-474.

Evacuasiany E, Ratnawati H, Liana LK, Widowati W, Maesaroh M, Mozef T, Risdian C (2014) Cytotoxic and antioxidant activities of catechins in inhibiting the malignancy of breast cancer. Oxid Antioxid Med Sci 3(2):141-146

Eric W, Eu Y, Pei P, Yon P (2011) Antioxidant and antibacterial properties of green, black, and herbal teas of Camellia sinensis. Pharmacognosy Res 3(4): 266-272.

Fransworth N (1966) Biological and phytochemical screening of plants. J Pharm Sci 55: 225-276.

Gramza A, Pawlak-Lemanska K, Korczak J, Sowicz E, Rudzinska M (2005) Tea extracts as free radical scavengers. Polish J Environ Studies 14(6):861-867.

Halliwell B, Gutteridge J (2007) Free radicals in biology and medicine. 4th ed. Clarendon Press, Oxford, UK

Han S, Lo S, Choi Y, Kim J, Baek S (2004) Antioxidant activity of crude extract and pure compounds of Acer ginnala Max. Bull Korean Chem Soc 25(3): 389-391.

Higdon J, Frei B (2003) Tea catechins and polyphenols: health effects, metabolism, and antioxidant functions. Cri Rev Food Sci Nutr 43:89-143.

Ivanova D, Gerova D, Chervenkov T, Yankova T (2005) Polyphenols and antioxidant capacity of Bulgarian medicinal plants. J Ethnopharmacol 96:145-150. 
Johnson P (2002) Antioxidant enzyme expression in health and disease: effects of exercise and hypertension. Comp Biochem Physiol 133: 493-505.

Krinsky N (1992) Mechanism of action of biological antioxidants. Proc Soc Exp Biol Med 200: 248-254.

Lai K, Yalun S, Ruoyun C, Zesheng Z, Yu H, Zhen-Yu C (2001) Theaflavins in black tea and catechins in green tea are equally effective antioxidants. JN 2001: 2248-2251.

Leung L, Su Y, Chen R, Zhang Z, Huang Y, Chen ZY (2001) Teaflavins in black tea and catechins in green tea are equally effective antioxidants. J Nutr 131:2248-2251.

Ling J, Mohamed M, Rahmat A, Abu Bakar M (2010) Phytochemicas, antioxidant properties and anticancer investigations of the different parts of several gingers species (Boesenbergia rotunda, B. puchella var attenuata and B.armeniaca). J Med Plant Res 4(1): 27-32.

Lobo V, Patil A, Phatak A, Chandra N (2010) Free radicals, antioxidants and functional foods: Impact on human health. Pharmacogn Rev 4(8):118-126.

McKay D, Blumberg J (2002) The role of tea in human health: an update. J Am Coll Nutr 21: 1-13.

Nagao T, Komine Y, Meguro S, Hase T, Tanaka Y, Tokimitsu I (2005) Ingestion of a tea rich in cathechins leads to a reduction in body fat and malondialdehyde-modified LDL in men. Am J Clin Nutr 81: 122-129.

Nor Q, Mohd F (2013) Phytochemicals and antioxidant properties of different parts of Camellia sinensis leaves from Sabah Tea Plantation in Sabah, Malaysia. Int Food Res J 20(1): 307-312.

Pujimulyani D, Wazyka A, Anggrahini S, Santoso U 2004. Antioxidative properties of white saffron extract (Curcuma mangga $\mathrm{Val}$ ) in the $\beta$-carotene bleaching and DPPH-radical scavenging methods. Indonesian Food Nutr. Progress. 2004, II(2): 35-40.

Satoh E, Tohyama N, Nishimura M (2005) Comparison of the antioxidant activity of roasted tea with green, oolong, and black teas. Int J Food Sci Nutr 56(8): 551-559

Tiwari P, Bimlesh K, Kaur M, Kaur G, Kaur H. (2011) Phytochemical screening and Extraction: A Rev Inter Pharm Sci 1(1): 98-106

USDA. (2003) USDA database for the flavonoid contents of selected foods Beltsville. US Department of Agriculture.

Vecchia C, Negri E, Francheschi S, D'Avanzo B, Boyle P (1992) Tea consumption and cancer risk. Nutr Cancer 17(1): 27-31.

Von G, Jouber E, Hansmann C (2000) Comparison of antioxidant activities of rooibos tea (Aspalathus linearis) on red blood cells of Japanese quails. Gen Physiol Biophys 19: 365-371.

Widowati W, Ratnawati H, Rusdi U, Winarno W, Immanuel V (2010) Phytochemical assay and antiplatelet activity of fractions of velvet bean seeds (Mucuna pruriens L.). Hayati J Biosci 17(2): 85-90.
Widowati W, Herlina T, Ratnawati H, Mosef T, Risdian C (2011a) Antioxidant activities and platelet aggregation inhibitor of black tea (Camellia sinensis L.). Med Plants 3(1): 21-26.

Widowati W, Sardjono CT, Wijaya L, Laksmiawai DR, Darsono L (2011b) Free Radicals Scavenging Activities of Spices and Curcumin. Proceeding of The Second International Symposium on Temulawak, ISBN No. 978-979-25-1209: 179181

Widowati W, Ratnawati H, Mozefis T, Pujimulyani D, Yelliantty Y (2013a) Hypolipidemic and Antioxidant Effects of Black Tea Extract and Quercetin in Atherosclerotic Rats. Int J Med, Pharm Scie Engineer 7(10):64-71

Widowati W, Wijaya L, Teresa L, Bachtiar I, Yellianty Y, Laksmitawati R (2013b) Antioxidant, anticancer, and apoptosis-inducing effects of Piper extracts in HeLa cells. J Exp Integr Med 3(3): 225-230.

Widowati W, Mosef T, Risdian C, Yellianty Y (2013c) Anticancer and free radical scavenging potency of Catharanthus roseus, Dendrophthoe petandra, Piper betle and Curcuma mangga extracts in breast cancer cell lines. Oxid Antioxid Med Sci 2(2): 137-142.

Widowati W, Ratnawati H, Wahyudianingsih R, Yelliantty Y, Maesaroh M, Pujimulyani D, Mozef T (2014a) Effect of green tea extract and epigallocatechin-3-gallate potency on lipid profile and coronary artery morphology of dyslipidemic rats. Oxid Antioxid Med Sci 3(2):147-152

Widowati W, Widyanto RM, Husin W, Ratnawati H, Laksmitawati DR, Setiawan B, (2014b) Nugrahenny D, Bachtiar B. Green tea extract protects endothelial progenitor cells from oxidative insult through reduction of intracellular reactive oxygen species activity. Iran J Basic Med Sci 17 ( 9):703-709

Widowati W, Ratnawati H, Husin W, Maesaroh M (2015) Antioxidant properties of spice extracts. Biomed Engineer 1(1): $24-29$

Wiseman S, Balentine D, Frei B (1997) Antioxidants in tea. Crit Rev Food Sci Nutr 37: 705-718.

Wolfram S (2007) Effects of green tea and EGCG on cardiovascular and metabolic health. J Am Coll Nutr 6(4): 373S-388S.

Xie B, Shi H, Chen Q (1993) Antioxidant properties of fractions and polyphenol constituents from green, oolong, and black tea. Proc Nat Sci Repub China 17:77-84.

Yang C, Landau J (2002) Effect of tea consumption on nutrition and health. J Nutr 130: 2409-2412.

Yang XN, Kang SC. 2011. In vitro antioxidant activity of the water and ethanol extracts of Forsythia koreana flowers. Nat Prod Res. 2011 Aug 24. Online available

Zhu Q, Hackman R, Ensunsa J, Holt R, Keen C (2002) Antioxidative activities of oolong tea. J Agric Food Chem 50: 6929-6934. 
